\title{
Measurement of genetically modified (GM) genes in different corn products
}

\author{
Meltem Asicioglu $^{\oplus 1,2}$, Burhanettin Yalçınkaya ${ }^{\oplus 1}$ and Muslum Akgoz $^{\oplus 1^{*}}$ \\ ${ }^{1}$ Bioanalysis Laboratory, TUBITAK National Metrology Institute, UME, P.Box:54, 41470, \\ Türkiye \\ ${ }^{2}$ Prof. Dr. Aziz Sancar Biological Clock Laboratory, Department of Molecular Biology and \\ Genetics, Gebze Technical University, 41400, Türkiye
}

(Received August 14; 2017; Revised October 19, 2017; Accepted October 21, 2017)

\begin{abstract}
Nowadays, genetically modified (GM) plants are widely used in several commercial products. Corn, cotton, soybean and canola are the most widely consumed foods globally and their derived products have reached the global markets. Specifically, corn has the greatest diversity of approved GM events globally (a total of 130 varieties approved in one or more countries). It is one of the most widely used food and feed ingredient, highly integrated into food and feed supply chains. Since GMOs carry environmental risks and human health related risks, it is required that the food and their ingredients that either contain GMOs or derived from GMOs should be labelled. In this study, we investigated the taxon-specific cauliflower mosaic virus 35S promoter region (CaMV) and Agrobacterium tumefaciens nonpalin synthase terminator (tNOS) gene in addition to the control gene of High Mobility Group (HMG). Corn-containing foods were obtained from grocery stores in Turkey. DNA extraction was performed by modified CTAB DNA extraction method for all samples and genomic DNA were extracted. The DNA extracts were screened by qPCR and it was shown that genetically modified DNA sequences of tNOS and CaMV were not present in the samples investigated. For the security of society, randomized screens should be carried out by scientist in random bases.
\end{abstract}

Keywords: Biometrology; food safety; GMO quantification; GMO screening; corn. ㅇ 2017 ACG Publications. All rights reserved.

\section{Introduction}

Recombinant DNA technology has been widely used in modern agriculture since the first commercial genetically modified (GM) plant (the Flavr Savr tomato) was approved for marketing in 1994 [1]. Production of genetically modified organisms (GMOs) has revolutionized the agricultural industry which has been increasing steadily worldwide. Corn, cotton, soybean and canola are the most widely consumed foods in several countries and their derived products have reached the global marketplace to 181.5 million tons by 2014 [2].

Several transgenic crops with beneficial characteristics have been developed by insertion of foreign microbial genes into the plant genomes. The most common GM plants are insect-resistant and herbicide-tolerant corn, soybeans and cotton plants. In contrast to important benefits of GM plants, known and unknown risks to human health and environment may prevail in future. For instance,

\footnotetext{
* Corresponding author E-Mail: muslum.akgoz@tubitak.gov.tr 
allergens and toxins due to antibiotic resistance markers may reveal health problems in short and long term. Cross pollination may lead to transfer of transgenes and this may cause the loss of flora and fauna biodiversity $[3,4,5]$. Specially, corn has the greatest diversity of approved GM events globally (a total of 130 varieties approved in one or more countries), and is one of the most widely used food and feed ingredients, highly integrated into food and feed supply chains [6,7].

Highly accurate measurement of GM genes is critical in food and feed product analysis. According to the European Union (EU) regulations, it is mandatory to label food and feed products containing more than $0.9 \%$ authorized GMO and more than $0.5 \%$ unauthorized GMO material for the consumer information [8]. Turkey also regulates GMOs according to EU labelling regulations. The regulation requests accurate monitoring and traceable detection of GMOs in raw materials of food and feed. As a result, several analytical methods have been developed and validated worldwide for GMO detection. The most widely used reference method for GMO detection approach is the Real-Time Polymerase Chain Reaction (qPCR) which is fast, cheap, and accurate [3,9] in detecting the presence of GMOs either accidentally or intentionally [10].

In this study, 11 different corn seeds or corn containing products were screened for the presence of CaMV and tNOS sequences using the taxon specific method. HMG (High mobility group) gene, an endogenous gene of corn was used as a control gene.

\section{Experimental}

\subsection{Sample collection}

Eleven corn samples were randomly collected from local markets selling both local and imported foods in Turkey. For sample identification, cornflakes, corn seed-1, corn seed-2, popcorn \& rice crisp, corn chips, popcorn, corn flour-1 and corn flour-2, corn starch, corn on the cob and canned corn samples were labelled from 1 to 11, respectively. MON88017 certified reference material was used as positive control material.

\subsection{Genomic DNA extraction}

All samples, except starch and corn flour, were homogenized after grinding and stored at $-80^{\circ} \mathrm{C}$ until analysis. Genomic DNA was extracted from homogenized samples using the modified CTAB (Cetyltrimethylammonium bromide) method [11]. Total DNA was extracted from $100 \mathrm{mg}$ sample, in triplicates. For each sample, $750 \mu \mathrm{L}$ CTAB extraction buffer and $20 \mu \mathrm{L}$ RNase A $(10 \mathrm{mg} / \mathrm{ml})$ was added. The suspension was mixed and incubated for $30 \mathrm{~min}$ at $65^{\circ} \mathrm{C}$. After incubation, $20 \mu \mathrm{L}(10$ $\mathrm{mg} / \mathrm{mL}$ ) Proteinase $\mathrm{K}$ was added and incubated for additional $30 \mathrm{~min}$ at $65^{\circ} \mathrm{C}$. The tubes were gently shaken for $2 \mathrm{~h}$ at $65{ }^{\circ} \mathrm{C}(1,200 \mathrm{rpm})$. After incubation, the samples were centrifuged for $10 \mathrm{~min}$ at $12,000 \times \mathrm{g}$. The supernatant was transferred into a new tube, then, 1 volume of chloroform was added and vortexed. The tubes were centrifuged for $15 \mathrm{~min}$ at $12,000 \times \mathrm{g}$ and upper phase was transferred to a new tube. 2 volumes of the precipitation buffer $(5 \mathrm{~g} / \mathrm{L} \mathrm{CTAB}, 0.04 \mathrm{M} \mathrm{NaCl})$ was added and incubated for an hour at room temperature. The samples were centrifuged for $15 \mathrm{~min}$ at $12,000 \times \mathrm{g}$ and discarded the supernatant. Pellet was dissolved with $350 \mu \mathrm{L}, 1.2 \mathrm{M} \mathrm{NaCl}$ then $350 \mu \mathrm{L}$ chloroform added and mixed well. The samples were centrifuged for $10 \mathrm{~min}$ at $12,000 \times \mathrm{g}$. The upper phase was transferred into a new tube and 0.6 volume of isopropanol was added and incubated for $20 \mathrm{~min}$ at room temperature. The samples were centrifuged for $15 \mathrm{~min}$ at $12,000 \times \mathrm{g}$ and aqueous phase was discarded. The pellet was washed with $500 \mu \mathrm{L}, 70 \%$ ethanol and then centrifuged for $10 \mathrm{~min}$ at 12,000 $\times \mathrm{g}$. After centrifugation, the supernatant was discarded. The precipitate was dried and dissolved in 50 $\mu \mathrm{L}$ of $1 \mathrm{x}$ TE buffer.

The DNA yield and purity was determined using NanoDrop 1000 spectrophotometer (Thermo Scientific, Wilmington, DE, USA). Integrity of the extracted genomic DNA samples was checked by loading $10 \mu \mathrm{L}$ of extracted DNA on DNA gel electrophoresis (0.8\% agarose gels) containing $\mathrm{EtBr}$ in 1x TBE (10 mM Tris base, pH: 8.0, $2.75 \mathrm{~g}$ Boric acid/L, $1 \mathrm{mM}$ EDTA buffer) [12]. 


\subsection{Real time PCR analysis}

PCR amplifications of DNA samples were carried out using Light Cycler ${ }^{\circledR} 480$ Real Time PCR Instrument (Roche, Germany) with SYBR® Green I Master Mix (Cat. No.04707516001, Roche, Germany). Forward and reverse primers (Table 1) were synthesized and purified by MOPC (Macrogen, South Korea). qPCR was performed in a total volume of $20 \mu \mathrm{L}$ with $5 \mu \mathrm{L}$ of DNA as template $(8 \mathrm{ng} / \mu \mathrm{L})$ unless there is enough DNA in the extract. After an initial denaturation at $95^{\circ} \mathrm{C}$ for $10 \mathrm{~min}, 40$ cycles of PCR was performed by denaturing at $95^{\circ} \mathrm{C}$ for $15 \mathrm{~s}$, annealing and extension at $60^{\circ} \mathrm{C}$ for 1 minute (HMG and tNOS) or annealing and extension at $69^{\circ} \mathrm{C}$ for $1 \mathrm{~min}(\mathrm{CaMV})$.

Table 1. Primer pair sequences and their target elements $[13,14]$

\begin{tabular}{|c|c|c|c|}
\hline Primers & Primer Sequences ( $\left.5^{`}-3^{`}\right)$ & Target gene & $\begin{array}{l}\text { Amplicon size } \\
\text { (bp) }\end{array}$ \\
\hline HMG-F & TTGGACTAGAAATCTCGTGCT & \multirow{2}{*}{$\begin{array}{l}\text { High Mobility } \\
\text { Group }\end{array}$} & \multirow{2}{*}{79} \\
\hline HMG-R & GCTACATAGGGACGCTTGTCC & & \\
\hline tNOS -F & GATTAGAGTCCCGCAATTATACATTTAA & \multirow{2}{*}{ Nos Terminator } & \multirow{2}{*}{69} \\
\hline tNOS $-\mathbf{R}$ & TTATCCTAGKTTGCGCGCTATATTT & & \\
\hline CaMV-F & AAAGCAAGTGGATTGATGTGATA & \multirow{3}{*}{ 35S Promoter } & \multirow{3}{*}{75} \\
\hline & & & \\
\hline CaMV-R & GGGTCTTGCGAAGGATAGTG & & \\
\hline
\end{tabular}

All samples were analyzed for the presence of tNOS and CaMV genes using qPCR method and PCR products were analyzed in $2 \%$ DNA agarose gels by visualizing under UV transilluminator using Ethidium Bromide. HMG gene was used as a positive control.

\section{Results and discussion}

A total of 11 samples of corn-containing foods were collected from markets in Turkey. All of samples were extracted by CTAB DNA extraction method.

The amount and purity of the extracted genomic DNA samples was determined by NanoDrop 1000 Spectrophotometer by measuring at $260 \mathrm{~nm}, 280 \mathrm{~nm}$, and $230 \mathrm{~nm}$. The concentrations of genomic DNA extracts are given in Table 2. Genomic DNA was found intact and visible for the samples of corn seed-2, popcorn, corn flour-1, corn flour-2, corn cob, although same degradation of genomic DNA is visible (Figure 1). The extraction efficiency of these samples was also higher than that of other samples (Figure 1). Degradation was observed with corn seed-1, corn chips and canned corn samples. Canned corn is heat processed, therefore, DNA degradation is considered normal. For corn flakes, popcorn\&rice crisp and corn starch samples did not reveal any genomic DNA bands at all, consistent with absorbance readings except, absorbance reading of popcorn\&rice crisp, $37 \mathrm{ng} / \mu \mathrm{L}$.

The ratio of absorbance $260 \mathrm{~nm}$ to $280 \mathrm{~nm}\left(\mathrm{~A}_{260 / 280}\right)$ represents the purity in terms of protein content and as the value is around 1.8 it is considered pure enough for PCR applications. Corn seed-2, corn chips popcorn, corn flour and corn cob has higher $\mathrm{A}_{260 / 280}$ values than 1.8 as well as positive control sample. As expected, highly processed cornflakes and Popcorn \& Rice Crisp samples exhibits very low levels of $\mathrm{A}_{260 / 280}$. Contamination with carbohydrates and other organic materials also lead to lower ratios of absorbance $260 \mathrm{~nm}$ to $280 \mathrm{~nm}\left(\mathrm{~A}_{260 / 280}\right)$ than 2.0. Similarly, processed cornflakes and Popcorn \& Rice Crisp samples exhibited lowest $\mathrm{A}_{260 / 280}$ values. 
Table 2. Determination of DNA concentration and purity by absorbance spectroscopy

\begin{tabular}{|c|c|c|c|c|c|c|c|c|c|}
\hline $\begin{array}{c}\text { Lane } \\
\#\end{array}$ & Sample Name & $\begin{array}{c}\text { Conc. } \\
\text { (ng/ } / \mu \mathrm{L})\end{array}$ & $A_{260 / 280}$ & $\mathbf{A}_{260 / 230}$ & $\begin{array}{c}\text { Lane } \\
\#\end{array}$ & Sample Name & $\begin{array}{c}\text { Conc. } \\
\text { (ng/ } \mu \mathrm{L})\end{array}$ & $\mathbf{A}_{260 / 280}$ & $\mathbf{A}_{260 / 230}$ \\
\hline $\mathbf{P}$ & Positive Control & 80 & 1.96 & 1.05 & 6 & Popcorn & 200 & 2.06 & 2.26 \\
\hline 1 & Cornflakes & 7.5 & 1.01 & 0.35 & 7 & Corn Flour-1 & 123.4 & 2.05 & 2.17 \\
\hline 2 & Corn Seed-1 & 92 & 1.68 & 1.07 & 8 & Corn Flour-2 & 44.8 & 1.73 & 1.34 \\
\hline 3 & Corn Seed-2 & 138 & 2.10 & 2.28 & 9 & Corn Starch & - & - & - \\
\hline 4 & Popcorn \& rice crisp & 37 & 1.34 & 0.46 & 10 & Corn Cob & 289 & 2.10 & 2.37 \\
\hline 5 & Corn Chips & 79 & 1.81 & 1.45 & 11 & Canned Corn & 509 & 1.69 & 1.70 \\
\hline
\end{tabular}

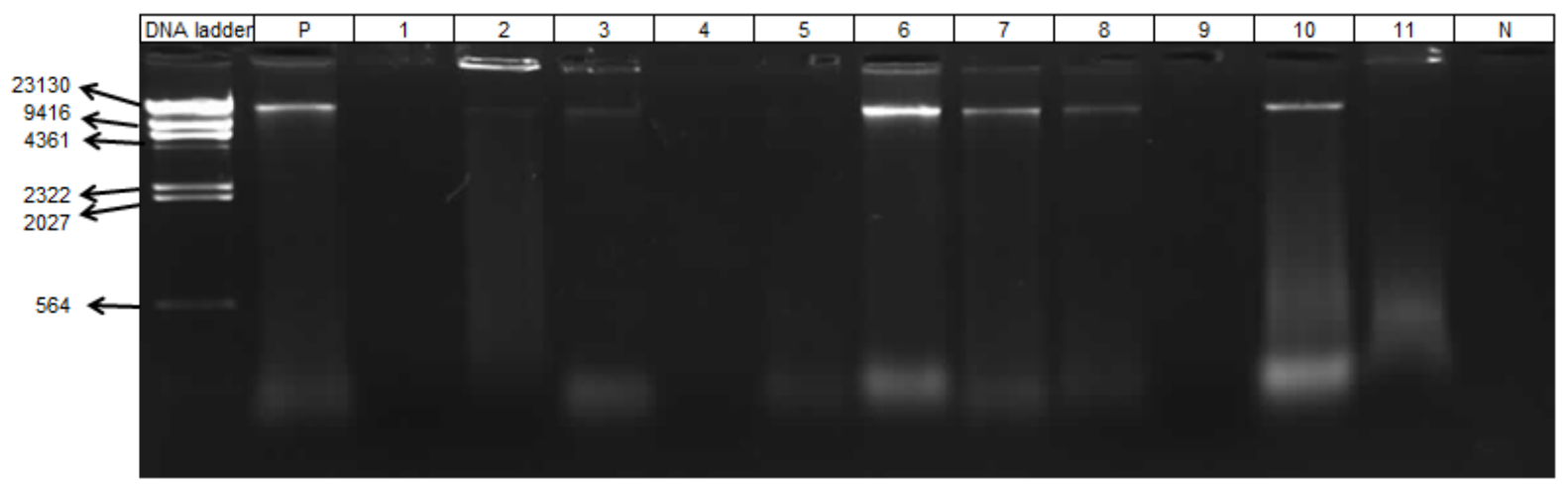

Figure 1. Extracted DNA samples were loaded and analyzed by DNA agarose gel $(0.8 \%)$ electrophoresis and visualized under UV light. Lanes: DNA ladder, Lambda DNA HindIII digest molecular weight standard marker; P: positive control; lane 1: cornflakes; lanes 2 and 3: corn seeds; lanes 4: Popcorn \& Rice Crisp; lane 5: Corn Chips; lanes 6: Popcorn; lanes 7 and 8: corn flour-1 and corn flour-2; lane 9: corn starch; lanes 10: cob and lane 11: canned corn; N: negative control.

Before the investigation of the presence of GMO sequences, to assure the amplification of DNA extracts in PCR, firstly, the extracted DNAs were tested with specific primers for an endogenous HMG gene. All tested samples, even if they are not visible on the DNA gels or even they are not detected with UV absorbance, resulted in 79 bp DNA bands, correct size for HMG gene (Figure 2). According to qPCR analysis, Ct values of samples differed significantly which evidence the presence of PCR inhibitors during the processing of products. Negative control lane did not reveal any signal.

Table 3. HMG gene qPCR result of samples

\begin{tabular}{clcclc}
\hline Lane \# & Sample Name & Ct Value & Lane \# & Sample Name & Ct Value \\
\hline $\mathbf{P}$ & Positive Control & 25,0 & $\mathbf{6}$ & Popcorn & 23,2 \\
$\mathbf{1}$ & Cornflakes & 31,5 & $\mathbf{7}$ & Corn Flour-1 & 24,8 \\
$\mathbf{2}$ & Corn Seed-1 & 23,7 & $\mathbf{8}$ & Corn Flour-2 & 24,1 \\
$\mathbf{3}$ & Corn Seed-2 & 24,4 & $\mathbf{9}$ & Corn Starch & 32,5 \\
$\mathbf{4}$ & Popcorn \& Rice Crisp & 31,5 & $\mathbf{1 0}$ & Corn Cob & 23,6 \\
$\mathbf{5}$ & Corn Chips & 23,6 & $\mathbf{1 1}$ & Canned Corn & 27,7 \\
& & & & Negative & - \\
\hline
\end{tabular}

Secondly, we tested the presence of cauliflower mosaic virus (CaMV) 35S promoter and Agrobacterium tumefaciens nonpalin synthase (tNOS) terminator DNA sequences, which are mostly present in several GMOs products worldwide [9]. These methods are available on CRL-GMFF database according to EU legislation [8]. Taxon specific method was applied to screen CaMV and tNOS gene sequences in collected samples. Real Time PCR method (qPCR) was utilized to compare 
relative extraction efficiency of the DNA extraction. The amplified DNA was run on 2\% DNA agarose gel to evaluate the correct size of DNA bands (Fig 2). The positive control sample (P) exhibited $69 \mathrm{bp}$ and $75 \mathrm{bp}$ PCR products for tNOS and CaMV genes, respectively, which are the correct band size. None of the samples revealed any PCR band specific for tNOS and CaMV genes. This mean that these samples do not contain any genetically modified DNA sequences for P35S or CaMV.

A.

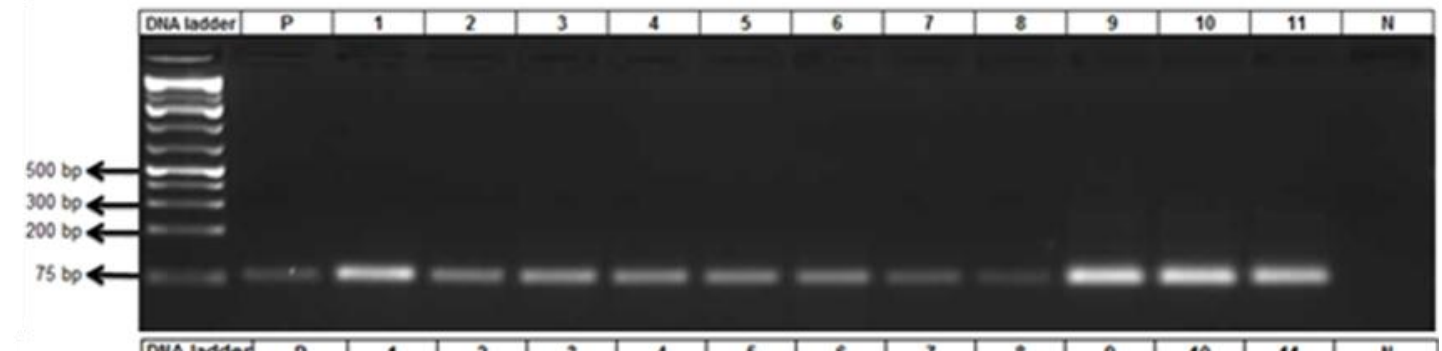

B.

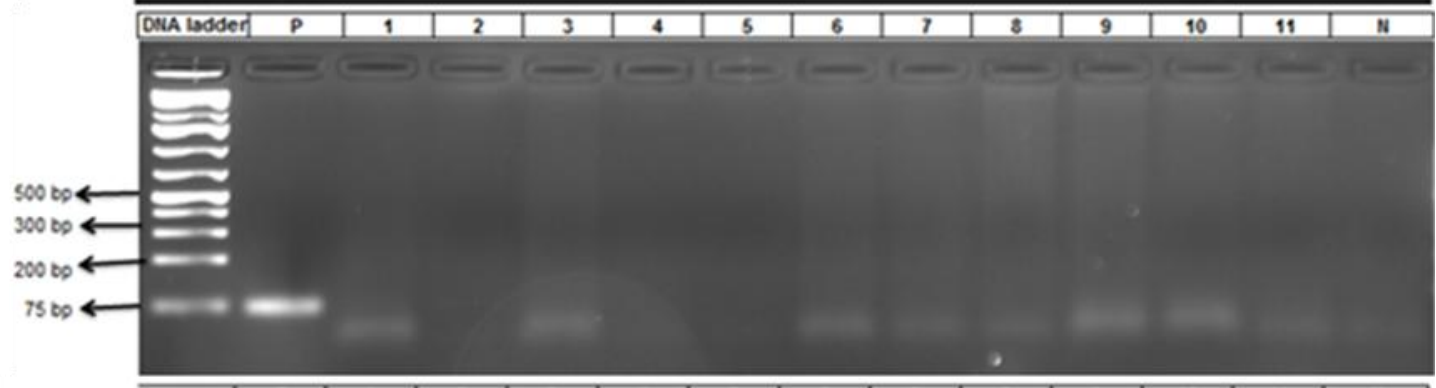

C.

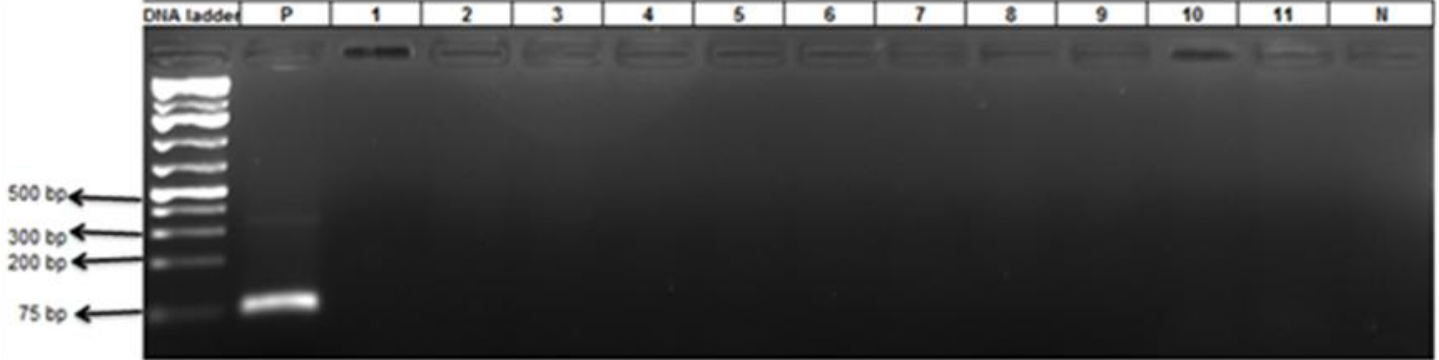

Figure 2. GMO analysis of corn samples. In addition to the control HMG gene (A), tNOS (B) and CaMV genes $(\mathrm{C})$ were screened with qPCR. The PCR products were analyzed in 2\% DNA agarose gel using gel electrophoreses. Gene Ruler 1 kb Plus DNA Ladder SM1333 was used as a DNA ladder. (P: positive control, $\mathrm{N}$ : negative control, lines 1-11: tested samples).

According to the European Commission GMO legislation, food and feed products containing more than $0.9 \%$ authorized GMO should be labelled for the consumer information. In this study, 11 corn containing foods, collected from Turkish market, were screened for the presence of genetically modified tNOS and CaMV genes. This study has shown that none of these samples carry the DNA sequences for CaMV and tNOS vectors. This kind of analysis should be carried out periodically to test the presence of GMO food and feed in each country on randomized timing.

\section{Acknowledgements}

We thank Food Molecular Biology Laboratory, TUBITAK MAM for the gift of MON88017 certified reference material, Merve Oztug for helpful comments on the manuscript, and Sema Akyurek for technical help.

\section{ORCID}

Meltem Asicioglu: 0000-0002-2718-794X

Burhanettin Yalçınkaya: 0000-0002-3744-6634

Muslum Akgoz: 0000-0001-5065-8087 


\section{References}

[1] D. Zhang and J. Guo (2011). The development and standardization of testing methods for genetically modified organisms and their derived products, J. Integrat. Plant Biol. 53 (7), 539-551.

[2] J. M. Lucht (2015). Public acceptance of plant biotechnology and GM crops, Viruses 7, 4254-4281.

[3] N. Datukishvili, T. Kutateladze, I. Gabriadze, K. Bitskinashvili and B. Vishnepolsky (2015). New multiplex PCR methods for rapid screening of genetically modified organisms in foods, Front. Microbiol 6, 757.

[4] A.S. Bawa and K.R. Anilakumar (2013). Genetically modified foods: Safety, risks and public concerns- A review, J. Food Sci. Technol. 50(6), 1035-1046.

[5] P. Gay and S. Gillespie (2005) Antibiotic resistance markers in genetically modified plants: A risk to human health, Lancet Infect Dis 5,637-646.

[6] N. Alasaad, H. Alzubi and A. A. Kader (2016). Data in support of the detection of genetically modified organisms (GMOs) in food and feed samples, Data in Brief 7, 243-252 DOI:10.1016/j.dib.2016.02.035

[7] A. Turkec, S. J. Lucas and E. Karlik, (2016). Monitoring the prevalence of genetically modified corn in commercial animal feeds and food products in Turkey, J. Sci. Food. Agric. 96, 3173-3179.

[8] A. Holst-Jensen, Y. Bertheau, M. de Loose, L. Grohmann, S. Hamels, L. Hougs, D. Morisset,S. Pecoraro, M. Pla, M. Van den Bulcke and D. Wulff, (2012). Detecting un-authorized genetically modified organisms (GMOs) and derived materials, Biotechnol. Adv. 30(6), 1318-1335.

[9] A. Turkec, H. Kazan, B. Karacanli and S. J. Lucas (2015). DNA extraction techniques compared for accurate detection of genetically modified organisms (GMOs) in corn food and feed products, J. Food Sci. Technol. 52(8), 5164-5171.

[10] N. T. Salihah, M. M. Hossain, H. Lubis and M. U. Ahmed (2016). Trends and advances in food analysis by realtime polymerase chain reaction, J. Food Sci. Technol. 53(5), 2196-2209.

[11] B. Yalçınkaya, E. Yumbul, E. Mozioglu and M. Akgoz (2017). Comparison of DNA extraction methods for meat analysis, Food Chem 221, 1253-1257.

[12] B. Yalçınkaya and M. Akgoz (2015). Halal authenticity of sausage samples by qPCR analysis, J. Chem. Metrol. 9(1), 16-21.

[13] C. Savini, M. Ermolli, M. Querci, M. Mazzara, S. Cordeil and G. Van den Eede (2008). Event-Specific Method for the Quantification of Corn Line 199 MON 89034 Using Real-Time PCR Protocol. JRC Scientific and Technical Reports CRLVL06/06VP

[14] E. Barbau-Piednoir, A. Lievens, G. Mbongolo-Mbella, N. Roosens, M. Sneyers and A. Leunda-Casi, et al. (2009). SYBR Green qPCR screening methods for the presence of "35S promoter" and "NOS terminator" elements in food and feed products, Eur. Food Res. Technol. 230, 383-393.

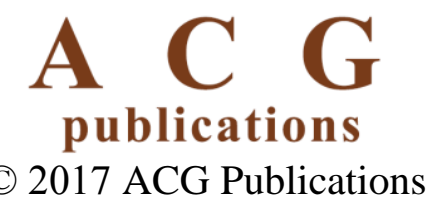

